\title{
The Timing of Motherhood While Earning a PhD in Engineering
}

\author{
Veronika Paksi \\ Centre for Social Sciences of the \\ Hungarian Academy of Sciences, Budapest, $\mathrm{HU}$ \\ paksi.veronika@tk.mta.hu \\ Beáta Nagy \\ Corvinus University of Budapest, Budapest, HU \\ beata.nagy@uni-corvinus.hu \\ Gábor Király \\ Budapest Business School, HU, and the \\ Corvinus University of Budapest, $\mathrm{HU}$
}

kiraly.gabor@uni-bge.hu

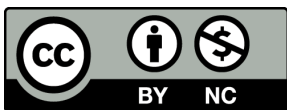

This article has been copyrighted by the Informing Science Institute on behalf of its authors. We license it to you under a Creative Commons AttributionNonCommercial 4.0 International License. When you copy and redistribute this paper in full or in part, you need to provide proper attribution to it to ensure that others can later locate this work (and to ensure that others do not accuse you of plagiarism). You may (and we encourage you to) adapt, remix, transform, and build upon the material for any non-commercial purposes. This license does not permit you to use this material for commercial purposes.
\end{abstract}

Abstract

In spite of tremendous efforts, women are still under-represented in the field of science. Postgraduate education and early tenure track employment are part of the academic career establishment in research and development during periods that usually overlap with family formation. Though women tend to leave science mainly after obtaining their $\mathrm{PhD}$, and the timing of motherhood plays a vital role in a successful research career, qualitative data on this life period are scarce. Our paper focuses on how the normative and institutional contexts shape female $\mathrm{PhD}$ engineering students' family plans. The research was based on intersections of life course and risk and uncertainty theories. Using qualitative interviews we explored how contradicting social norms of childbearing cause tensions in postgraduate students' lives, and how the different uncertainties and risks permeate young researchers' decisions on early life events. We concluded that, despite the general pattern of delaying motherhood among higher educated women, these students struggle against this postponement, and they hardly have any good options to avoid risk stem-

ming from uncertainties and from some characteristics of studying and working in engineering. Findings of this research may call the attention of stakeholders to possible intervention points.

Keywords: $\mathrm{PhD}$, timing of motherhood childbearing, women, uncertainty, life course, engineering

\section{Introduction}

Although the proportion of women among $\mathrm{PhD}$ recipients has slightly increased during the last decades in developed societies, it is still lower than that 
of men, especially in the fields of science, technology, engineering and mathematics (STEM). Despite the widespread use of the leaky pipeline metaphor (Berryman, 1983), several researchers argue for using a more complex explanation to understand women's constrained careers in male dominated technical fields; namely, the life course perspective (Xie \& Shauman, 2003; Castaño $\&$ Webster 2011). This approach might be particularly fruitful in the case of young researchers since the ideal period of career establishment usually overlaps with the ideal timing for family formation (Mason, Wolfinger, \& Goulden, 2013). The standard academic career model hardly supports career breaks and expects individuals to move along the academic pipeline from school to degrees to academic positions in short order. Moreover, youths often face several uncertainties during their early life course, especially due to their fragile economic status (Blossfeld, Klijzing, Mills, \& Kurz, 2005). Difficulties can be more acute in male-dominated occupations in STEM fields (Xie \& Shauman, 2003), and are especially challenging in the case of Black women for historical reasons (Hendrix, 2007).

In order to gain insight about the above-mentioned processes in a post-socialist context, namely in Hungary, we offer a qualitative life course approach to explore the dilemmas and tensions young female engineers are faced with in research and development. In particular, we wish to contribute to the academic discourse on how conflicting processes of standardization and destandardization might shape academic women's private and professional choices in a country where there has been a clear backlash against women's emancipation after the collapse of the state-socialist regime (Kř́̌žková, Nagy, \& Kanjuo, 2010).

The paper consists of seven sections. In the first section we briefly discuss the theoretical part of our research project. The second part introduces the previous empirical findings in relation to young scientists. The third part puts these theories and processes touched upon into context by discussing the Hungarian situation in relation to these issues. The fourth part aims to describe our methodology - both data gathering and analysis - in a transparent way. The fifth part is the heart of the paper where we present our research findings. In the sixth section we discuss the possible contributions our paper makes to the existing theoretical and empirical results, and in the last section we summarize the paper and draw the main conclusions.

\section{Theoretical Background}

Two main theoretical approaches seemed to be particularly fruitful for the understanding of the situation of young scientists. Life course approach explores the continuous clashes between professional and private life events, while the exploration of risks and uncertainties points at the changing social and economic context causing challenging circumstances for young professionals. We are well aware that Blossfeld's (2007) theory about uncertainties and Beck's (1992) risk theory are based on different philosophical and methodological backgrounds. Nevertheless, for the sake of simplifying the train of thought and because they analyze similar processes, in this paper we intentionally downplay their differences and discuss them together. In the following section we will discuss all these different strands of social theory briefly.

\section{The Life Course Approach}

In the academic literature, the term 'second demographic transition' refers to the historical phase that started in the 1960s. It can be characterized among others by sub-replacement fertility, a decline of marriage, and an increase in divorce, ruled by the increased importance of individual choice (Lesthaege, 2010, p. 212). Even if there is a high variability in Western societies, there are clear demographic tendencies, such as the postponement of parenthood and decreased fertility. Lesthaege argues that East European post-communist countries also follow this general pattern, and women's increased educational level and growing demand for independence indeed do seem 
to have had a negative effect on women's fertility levels in these countries as well. Life course research might contribute to the understanding of these changes: as the theory emphasizes, life courses are the results of various mechanisms, like social structures, culturally coded beliefs, age norms, institutionalized transitions, individual decisions, socialization processes and selection mechanisms (Mayer, 1993, p. 112).

In the last decades of the $20^{\text {th }}$ century, however, a growing body of evidence documented the process of individualization, and the de-standardization of life courses (Lesthaege, 2010 p. 212; Kohli, 2007). The question arose, how this general tendency of de-standardization actually takes place in present-day European societies. In a detailed examination of the dynamics of destandardization, Huinink (2013) differentiated three main groups of life course dimensions: events (transitions), states and trajectories. In his approach "de-standardisation means that the level of standardisation is declining", Huinink (2013, p. 101) concluded that besides destandardization (e.g., the pattern of leaving the parental home significantly differs in North and South Europe), the re-standardization of life courses (e.g., the widespread general pattern of the postponed first childbirth) can be present at the same time. This supports Kohli's (2007, p.259) argument that institutional continuity is coupled with some de-standardization, but we cannot speak about de-standardization in general.

Life course analysis used to be gender blind, and generalized the experiences of typical male life courses. Kohli (2007) expresses his view that the tripartite structure of life courses - education, employment and pension - has become highly institutionalized, and this has been increasingly valid for women as well (Kohli, 2007, p. 262). Looking at the phase of education, it is obvious that the years spent in education play a crucial role in women's lives in all developed countries. In spite of the increasing influence of the individualization processes, it is still a widely accepted opinion that youths should only establish a family after they have finished school (Mynarska, 2010, p. 355; Bernardi, Klarner, \& von der Lippe, 2008, p. 303). It can be stated that with the assertion, "age-relatedness of career related transitions remains stronger than relatedness of family related transitions", Huinink (2013, p.104) refers to Corijn and Klijzing's work from 2001, as education and income are more required for a successful life. Therefore, the timing of motherhood in general, and the timing of the first childbirth in particular, play a distinct role in a professional career.

Concerning paid work, we can witness a considerable convergence between male and female life courses. Still, the timing of life events and reconciliation of the different life domains remained a difficult issue for women. Household chores seldom became a fairly divided task between spouses; moreover, women and men start their working careers with similar conditions, but finish with huge differences regarding money, power and prestige (Xie \& Shauman, 2003, p. 210; Sørensen, 1990, p. 314). As a consequence, women either postpone childbirth, or often give up their career perspectives. This can be a particularly great sacrifice in the Central-Eastern European (CEE) context, where flexibility is not an integral part of labor market policies (Kř́žková et al., 2010). These circumstances worsen further due to the changing and uncertain societal environment.

\section{Insecurity and Changing Life Courses}

While the theory of the second demographic transition clearly emphasizes the power of value changes and individualization processes, Beck (1992) interprets this phenomenon from the viewpoints of, among others, risk and individualization. Although Kohli (2007) emphasized the institutionalization of the individual options, Beck argues that individualization means breaking away from traditional ways. Traditional certainties acting through the structures of age, gender and social class have disappeared, while individuals must face an increasing number and new types of 
personal risks, such as risks due to unstable labor market conditions, instability of marriages and family disintegration (Beck, 1992). In line with these phenomena, economic and social changes and risks result in growing uncertainty among actors at the state, market, and individual levels. Certain groups are more seriously affected than others. Beck also highlights the status of women in the labor market, as part of the "working poor," as they experience "un-guaranteed and unstable forms of employment" more frequently than men (Beck, 2000, p. 106).

In a similar fashion, Blossfeld et al. (2005) point out that youths are particularly exposed to economic changes. Their difficulties as new entrants to the labor market and their economic uncertainty keep growing, while they have low incomes with precarious employment, unstable socioeconomic status and uncertain fixed-term work contracts that may easily be modified (Blossfeld, 2007, pp. 27-28). Uncertainty and forced adaptation also affect university lecturers and researchers. In the last decades, it has been a general tendency that the academic employment market has become increasingly unfavorable all around the world. On the one hand, this is manifested by the fact that there are fewer career-track positions open, thus newcomers have less chance of finding full-time initial positions (Altbach, 2000, p. 14). Moreover, chances of promotion have also decreased since "many countries have imposed quotas on promotions to senior ranks" (Altbach, 2000 , p. 15). Therefore, young scientists entering into the academic world are often faced with very bleak career prospects and many of them are kept in underpaid junior positions (Altbach, 2000 , p. 15). These changes in the academic sphere bear a strong resemblance to the general societal trends described by Blossfeld and Beck. Institutions of higher education are challenged and affected by an elevated level of risk (Beck, 1992) and unprecedented uncertainty (Blossfeld et al., 2005).

Apart from the risk stemming from uncertain labor market conditions, it is important to remember that the original concept of risk was related to new kinds of environmental and health risks generated by late-modernity. These risks were new because they are invisible in the sense that they are beyond human perception (Beck, 1992). This means that they are socially constructed in the sense they only "exist" in terms of our knowledge about them. This means that we can only react to them individually or socially if we are aware of their existence (Lupton, 1999). The anxiety of the highly educated is not relieved by their knowledge since they are only more aware of their inability to know "enough" about the different risks and to control their exposure to them. Beck (1992) also challenges scientific risk assessment practices since it is very difficult to quantify these new types of risks due to the cumulative effects of exposure and the effects of cross contamination by several substances. As will be discussed in the results section, this aspect of the risk society is particularly important since our research subjects are female $\mathrm{PhD}$ students working with chemicals in laboratories.

\section{Previous Research Findings}

Our research objectives were to: (a) map the different normative and institutional forces that shape female PhD students family plans, in general; and (b) explore the special features of engineering that influence the timing of childbearing, in particular. Despite its topical nature, the issues of women in academia in general and young female scientists in STEM fields particular are still relatively under-researched. In this section we briefly discuss the most important empirical findings of the last decade according to our theoretical framework and research objectives. Accordingly, the first part of this section focuses on the first research objective and shows what kinds of normative and institutional forces are revealed by previous studies concerning family plans. In this part, issues such as gendered life courses, the effect of child-bearing on career and labor market uncertainty will be touched upon. The second part focuses more on the second research objective, on the special circumstances; that is, on the male-dominated working cultures of STEM and the question of ethnicity. 
Research into "women in science" has significantly changed since Xie and Shauman (2003) have called attention to the idea that, besides structural constraints and women's preferences, family background plays an important role in women's career orientation. The authors argue that a life course approach is needed to better understand how female careers are constructed. Using representative quantitative datasets, Xie and Shauman carried out a thorough cohort analysis of female life courses in science and technology. They found that "being married and having children create career barriers that are unique to women scientists" (Xie \& Shauman, 2003, p. 210). Moreover, young women with children tend to have the highest probability to give up their careers in the USA. Another research based on empirical evidence from Spain and the UK (Castaño \& Webster, 2011) constructed an analytical framework to understand women's life courses in maledominated fields. The authors note that women very often do not follow the linear male career life course, but rather "move in and out of education and the labor market in response to their changing domestic circumstances and family relationships" (Castaño \& Webster, 2011, p. 368). These results refer to the highly gendered life courses in academia, where - as Xie and Shauman (2003) emphasized - female family choices are hardly voluntary or rational, but rather reflect the social structure. This leaves young mothers to face dilemmas with few good choices.

As we described in the theoretical part, the timing of motherhood is vitally important in female researchers' careers. For example, having the first child shortly after obtaining a PhD significantly decreases the probability of getting tenure: young mothers with children under the age of six are less likely to get a tenure-track job than women without children, and are less likely to receive a tenure track position than their male colleagues (Mason et al., 2013). It is still an unanswered question in the academic discourses what the "ideal" or at least the "least bad" timing of the first child is, if a woman aims at achieving a career in research and development. Statistical data shows that post-graduate students usually obtain the $\mathrm{PhD}$ degree at the beginning of their 30ies (NSF report 2014, table 54), after which they start to secure a tenure track position. Meanwhile, Jacobs and Winslow (2004) in their study concluded that women in academia are hardly able to delay childbirth not even until achieving tenure in the USA. Public opinion in European countries about the age norms of motherhood is clearly in line with these findings: firstly, women consider the "ideal" age of becoming a mother at around the age of 25 (in 2006) (Paksi \& Szalma, 2009, p. 66); secondly, examining the biological limit women set for themselves, Mynarska (2010) found the age of 30 as the most frequently perceived culturally defined deadline of motherhood.

Apart from the uncertainty and tensions in relation to the timing of the first child, women can experience high-level labor market uncertainty and risk in knowledge-intensive STEM professions. Based on Beck's (1992) and Blossfeld et al.'s (2005) theories (2005), Király, Luksander and Paksi (2013) examined how uncertainty affects the different social groups in 27 European countries. Results reassured that, though labor market uncertainty negatively correlates with the level of education, women and youths especially face long-term unemployment and fixed-term contracts at increasing rates. Moreover, disadvantageous labor market positions, such as having short, fixed-term contracts, and disadvantageous working conditions often go hand in hand. As a preliminary study about young academics showed (Friesenhahn \& Beaudry, 2014), young scientists shoulder heavy - 55 work hours a week - workloads in all of the 12 European countries surveyed (Friesenhahn \& Beaudry, 2014, pp. 55-56). The report concluded that, apart from heavy workloads, academic life is characterized by long hours, conflicting demands, and growing stress levels (Barrett \& Barrett, 2008; Tight, 2010). The effects of this unfavorable situation are apparent even in the case of doctoral recipients in engineering and physics, where the lowest proportion of married and cohabiting students (NSF report 2014, table 62) may refer to the difficulties student face in these highly male-dominated fields.

A huge body of literature tried to explain the reasons for the low representation of women in science. It revealed several institutional constraints and cultural paradoxes that significantly influ- 
ence how women can (or cannot) integrate motherhood into a research career (Nagy \& Paksi, 2014; Blickenstaff, 2005). Women are often marginalized in the prevailing masculine culture of engineering workplaces (Ayre, Mills, \& Gill, 2013), they hardly find any female role models or mentors to follow (Hayes \& Biglerb, 2013), receive less organizational support for balancing their work and family life (Evetts, 1994), and often face occupational segregation, biased evaluation, inflexible structure of academia, and the masculine view of science. Reflecting on our second research objective, all these hindrances are especially valid for male-dominated working cultures in STEM, such as it is in engineering, and all influence female life courses, especially motherhood decisions. However, the question of how all these affect the timing of childbearing is a "black box" in the academic literature, as well as the effects of the hazardous substances used in laboratories. Therefore, our results on the special features of engineering will provide a unique insight into this professional field.

The situation of Black students is even less favorable in research and development. Firstly, their representation in science is even lower than that of their White counterparts (Hilton \& Lee, 1998). Secondly, their socialization process as researchers is merely associated not just with gender but ethnicity (Eccles, 2005), and this intersection implies an especially challenging academic environment for them (Hendrix, 2007). In addition to obstacles women typically experience during their early academic career in science (Xie \& Shauman, 2003), Black women have to face hindrances permeated by historical racism, discrimination and prejudice (Frierson, 1990), all contributing to the chilly, not supportive environment that often discourage from choosing a career or staying in science (Jones, Osborne-Lampkin, Patterson, \& Davis, 2015).

Summarizing the introduced empirical findings, it can be seen that environment in academia is hardly supportive toward childbirth in academia. Unfavorable working conditions are more typical in the case of the early stages of academic life causing conflicting demands between private and work-related spheres of life. Meanwhile, young researchers want both to establish a family and "earn their name" in their field and they continuously fight their way up in the academic hierarchy (Probert, 2005; Haynes et al., 2012; Martinez, Ordu, Della, Matthew, \& McFarlane, 2013). These results also imply the outcome that young people, particularly women, if they want to stay in academic life, have to prioritize work against private life, and therefore postpone childbirth. The described gender and ethnic imbalance also anticipates the problems female $\mathrm{PhD}$ students face while starting their family life very often in parallel with their research work. Our qualitative research therefore will explore the influencing factors of engineering $\mathrm{PhD}$ students' family plans in details. Empirical results will show that these parallel life goals can generate a heightened sense of internal tension and unease in young academics.

\section{The Hungarian Context}

While the study of young scholars might be a "universal" topic, the results of our research can be better understood if the context is also delineated. Therefore, in this section we briefly present those Hungarian societal and institutional characteristics, which are important in the contextualization of our research findings.

As far as transitory life phases are concerned, it can be stated that Hungarian youths postpone the events of leaving of the parental home and marriage as well. These trends contribute to the delay of motherhood (Pongrácz, 2012, p. 14). This postponing attitude and behavior regarding marriage and childbearing in Hungary is not a new phenomenon; it started before the change in the political system (Tóth, 2002). Still, even today women give birth to their first child around the age of 29.5, a year earlier than the EU28 average (Eurostat, 2013).

Despite the widespread "practice of postponement", international survey results demonstrate that Hungarian society is very family-oriented (Pongrácz \& Molnár, 2011). The majority of the popu- 
lation considers family life more important than work, and a significant majority of women consider children a vital part of their life (Spéder, 2009, p. 34; Pongrácz \& Molnár, 2011). Besides, there is a very strong social agreement in the country that mothers should stay at home until the child turns three (Blaskó, 2005). This apparent conflict is also present at the micro level. Although Hungarians intend to have at least two children (Spéder, 2007), the fertility rate is one of the lowest in Europe (1.34) (Eurostat, 2012).

It is also important to mention that the backlash against women's emancipation and the strong signs of re-familization have also hampered the reconciliation of work and childbirth for women (Nagy, 2009; Kř́žzová et al., 2010). Both the gender segregation of the labor market and the traditional gender attitudes (Blaskó, 2005) limit women's career opportunities considerably. Moreover, the structural changes of the 1990s diminished the demand for research and development professionals in general (Fábri, 2008), and for women in engineering in particular (Palasik \& Papp, 2007, p. 4). Consequently, women are very much under-represented in the field of engineering (She Figures, 2012). The participation of women working toward an engineering $\mathrm{PhD}$ has always been very low in Hungary (around 30\%). This proportion is higher in chemical engineering, where nearly half of the students are women (KSH, 2009).

As for the social and life conditions of $\mathrm{PhD}$ students, it is important to note that state funded $\mathrm{PhD}$ scholarships do not provide enough money to become financially independent and to leave the parental home. Moreover, while PhD courses in Hungary take three years officially, students often postpone some semesters. With all possible options used, $\mathrm{PhD}$ studies can even be lengthened to eight years. Consequently, receiving a PhD degree typically occurs between the age of 30 and 34 (KSH, 2011). However, information is scarce on how Hungarian students harmonize their studies, work, and private life. Fináncz (2007) analyzed the regional survey data for PhD students belonging to various disciplines, and investigated both their career and their private plans. The results showed that one fifth of the students already had children at the time of the research; another fifth, however, did not find children an essential part of life, and $2 \%$ clearly rejected the idea of having children. Students postponed or did not plan family formation due to financial or career-related reasons, or because they worked abroad or - particularly in the case of women lacked a partner (Fináncz, 2007, p. 493).

\section{Methodology}

Based on the literature introduced above, our paper aims to highlight how $\mathrm{PhD}$ attendance in engineering affects women's family plans, especially the timing of their motherhood. Our research problem and questions are rooted in the constructivist paradigm presupposing that people actively create and shape their social reality through their understandings, meanings and practices. Doing research about these aspects is especially important since people make decisions, interact with each other and shape their environment according to their subjectively lived realities (Creswell \& Clark, 2007, pp. 37-43). Our approach is also in line with these considerations aiming to shed light on the subjective reality and experienced dilemmas of doctoral students. Accordingly, we conducted an exploratory research project using semi-structured interviews during the spring of 2014. The research questions were the followings:

(a) How do normative and institutional contexts shape female $\mathrm{PhD}$ students' family plans?

(b) How do special features of engineering influence the timing of childbearing?

\section{Methods}

Data for the research was gathered by qualitative methods that process is "an inquiry process of understanding a social or human problem based on building complex, holistic picture, formed with words, reporting detailed views of informants, and conducted in natural setting" (Creswell, 
1994, pp. 1-2). The research was embedded in the dual framework of life course and uncertainty/risk theories. The life course theory takes into consideration that human life courses are multidimensional, gendered, and that the timing and the relation of the different life events are of the utmost importance. It helps us to identify the major factors that influence starting, finishing and postponing different life phases in the case of young female scientists. The uncertainty and risk approach provide an insight how recent societal challenges shape individual life courses. These theories will help us to better understand how female professionals' life courses are formed at the threshold of tenure track employment.

We applied a semi-structured interview technique. Due to the exploratory character of our research, the interview guide was strongly influenced by our personal knowledge, experience, and informal preliminary work as well (King, 2004). The interview guide focused on two main themes:

(1) Facilitating and constraining factors of childbearing during the course of $\mathrm{PhD}$

(a) the ideal time of women's childbearing in engineering

(b) experienced uncertainty around family plans

(2) Special features of engineering that influence childbearing.

For the analyses, template analysis was applied with hierarchical coding defined by King (2004) where similar codes were clustered together to generate more general, higher-order codes. The "codebook" of the analyses was based not just on our existing knowledge, but on the initial analyses of the data as well (King, 1994).

We are, of course, well aware that the reconstruction of the past is subjective, and informants can be inaccurate when giving answers about specific details of their lives in the past (Bernard, Killworth, Kronenfeld, \& Sailer 1984; Hareven, 1991; Hirst, Coman, \& Coman, 2014) and these answers might change if they are asked later (Conway \& Pleydell-Pearce, 2000). However, the main point in our study was not to provide an accurate account of their life histories, but to grasp the tensions and dilemmas experienced in the present by our interviewees (see the distinction made between life story and life history in Jedlowski (2001)).

\section{Sampling and Sample Description}

The target group consisted of individuals who pursued a $\mathrm{PhD}$ course in the field of chemical and biological engineering. We conceptualized "to pursue a $\mathrm{PhD}$ course" as the following: individuals who are enrolled in doctoral schools, within the official time limit of the program and have not received their degree yet. We used the age of 40 as an upper age limit considering that our main goal was to reveal PhD students' perceptions and personal experiences on the timing of motherhood and $\mathrm{PhD}$ education.

The sample was composed of 11 female PhD students aged between 23 and 31 years, 10 chemical engineers and 1 biological engineer. Their socio-economic background is summarized in Table 1 . Individuals were selected from one engineering doctoral school of the Budapest University of Technology and Economics in Budapest, in order to have as homogeneous a group as possible. Contacts with the students were established through the head of the doctoral school.

Since our study was focused on female engineering $\mathrm{PhD}$ students whose number is rather limited, our sample was based on a purposeful sampling logic, which is based on the selection of information-rich cases of interest (Palinkas et al., 2015). In this sampling technique, those participants are looked for who have specific characteristics and/or knowledge purposefully informing the researcher (Creswell, 2007, p. 125; Higginbottom, 2004). This technique is especially useful if research subjects are not available in sufficient numbers to be reached by other sampling techniques (Berg, 2001, p. 32). 
Table 1. The socio-economic background of the interviewees

\begin{tabular}{|r|l|l|l|l|l|l|}
\hline Nr & Age & Marital status & Parental status & $\begin{array}{l}\text { PhD fellow- } \\
\text { ship }\end{array}$ & Workplace & $\begin{array}{l}\text { Labor- } \\
\text { atory }\end{array}$ \\
\hline 1 & 24 & Single & Childless & State & No & Yes \\
\hline 2 & 28 & Married & 1 child & State & Industry & Yes \\
\hline 3 & 31 & Single, cohabits & 1 child & State & Academia & Yes \\
\hline 4 & 28 & Single, cohabits & Pregnant & State & Academia & Yes \\
\hline 5 & 28 & Single & Childless & State & Academia & Yes \\
\hline 6 & 26 & Single, cohabits & Childless & State & No & Yes \\
\hline 7 & 31 & Single & Childless & State & Other public institute & Yes \\
\hline 8 & 25 & Single, cohabits & Childless & Industrial & No & No \\
\hline 9 & 28 & Married & Childless & State & Academia & Yes \\
\hline 10 & 28 & Single, cohabits & Childless & Industrial & University & No \\
\hline 11 & 29 & Married & Childless & Industrial & Industry & Yes \\
\hline
\end{tabular}

\section{Results}

Based on the analysis of our interviews, we have quite a clear view on the timing of $\mathrm{PhD}$ education and the first child in the field of engineering. Firstly, we will introduce students' main strategies concerning the timing. Secondly, we will show the explanations and dilemmas students have related to these strategies. This study focuses on $\mathrm{PhD}$ students with and without children; therefore, it discusses students' plans and real fertility behaviors in the context of uncertain socioeconomic circumstances.

\section{The Timing of the First Child}

The majority of our interviewees were aged between 28 and 31 years; therefore, the timing of motherhood was a fraught issue for all of them. They felt that the tension between the timing of childbearing and studies is a crucial conundrum in their lives.

In line with this, all $\mathrm{PhD}$ students in our sample conceptualized that, in their profession, there is no such thing as an "ideal period" for having the first child if someone aims to obtain a $\mathrm{PhD}$ degree. Seemingly, they are aware and able to reflect on the several disadvantages of each period, as well as on the few possible advantages. These pros and cons are related to options such as becoming a mother before, during or after $\mathrm{PhD}$ education. In general, they see three options in terms of timing: having their first child (1) before, (2) during, and (3) after their PhD studies. Severe dilemmas arise if any of these options are considered seriously. From the interviews it became evident that students could not find a good or best option. Therefore, the majority think about the "least bad" option: having their first child during their PhD study. It was a difficult decision for them, and they were still highly uncertain about it. This result is in harmony with earlier findings of Castaño and Webster (2011) that young mothers' decisions are shaped more by social and normative pressures, rather than by their perceived best choices.

In order to understand their uncertainty, we should consider the dilemmas that influenced their planning and/or decisions on the timing. These dilemmas can be located into three different dimensions. The most significant dimension is the conflict between individuals' norm to finish 
one's education before establishing a family and the perceived pressure running out of the "ideal" age of motherhood. The second dimension of dilemmas is related to the questions of how and when to have a career break due to childbearing; a dilemma that occurred in every option. The third dimension is given by the special features of engineering; this is the question of the health hazards of laboratory work. The next three subsections will give a detailed account of these dimensions.

\section{Finished PhD Education versus "Ideal” Age for Motherhood}

In harmony with the accepted social norm, there was an almost unanimous agreement amongst students that women should not become mothers before finishing school. This was clearly evident in the case of graduation years, and in the majority of the cases they shared this opinion in relation to $\mathrm{PhD}$ education as well. Answers concerning their own experience showed that delaying motherhood due to $\mathrm{PhD}$ enrollment is a widespread pattern.

The most significant dilemma for female $\mathrm{PhD}$ students related to the timing of their first child can be traced back to the tension between the defining social norm and the perceived feasibility of their family plans. On the one hand, they emphasized the advantages and the social expectations of the completion of educational qualifications before childbearing. On the other hand, they also felt they would "run out" of time for the "ideal" age of motherhood. Nevertheless, it became obvious after the interviews that though students found it the "least bad" option to become a mother during $\mathrm{PhD}$ education, it was a dominant view that $\mathrm{PhD}$ study delays the timing of the first child. The vital issue of the "good" timing had an utmost importance for the interviewees, which result reflects on Jacobs and Winslow's (2004) conclusion that women in academia can hardly delay childbirth until receiving tenure. As our interviewees put it:

Well, I think it is exactly the PhD that influences this. Because students, who do not take a PhD course graduate at the age of 24, just get a job, work for two or three years ... and then I think they can easily have children. ( $\mathrm{rr} 10$ )

It is obvious if someone starts to work after graduation, then her life will be completely different. For example, she should not count (the years) and feel that it would be great to give birth to a child at least till the age of 30. ( $\mathrm{nr} 9$ )

Nevertheless, finishing doctoral school before childbearing seemed to play a somewhat less significant role in students' lives: some of them found the postgraduate program suitable for childbearing. One might presuppose that the strong social norm of finishing school before parenthood is weakening over lifetime. However, based on the interviews, we found that this norm was still strong during $\mathrm{PhD}$ education, but, after a certain age, it was overcome by a stronger social pressure. Finishing school implied that it would be too late for these women to have their first child. Several $\mathrm{PhD}$ students mentioned parental pressure, perceived biological risks and physical problems that all drove them to have their first child within a short time.

The majority of the students interviewed considered the age of 30 a turning point of their life course, as it was the case in Mynarska's (2010) empirical findings. They perceived that to become a mother one is "young" under the age of 23, at the "ideal age" up to the age of 30 , while they consider someone "too old" to have their first child in their thirties. That is why, after a certain age, female $\mathrm{PhD}$ students' need for establishing a family proved to be a more decisive factor than finishing school. Although embarking on a course of $\mathrm{PhD}$ study involves a three-year enrollment in doctoral school, students are aware of the fact that writing a dissertation usually takes another two or three years. This means that a typical female $\mathrm{PhD}$ student is at least around 28-32 when she obtains her $\mathrm{PhD}$, which is the overall case in post-graduate education (see NSF report 2014, table 54): 
On my first day at the university I was told that it takes five or five and a half years on average, plus some post-doctoral years abroad ... but by that time (when having my first child) I will be well over thirty, around 32. And I am not sure that I want to start establishing a family so late. [...] Well, if a woman delivers her child around the age of 35, it is a little bit late and she has to count on health risks. (nr 10)

The pressure of having children before growing too old was more intense in the case of those students who enrolled into the $\mathrm{PhD}$ program later than the age of 23-24; therefore, they were older than their peers:

[...] I also started my PhD later, when I was 26, and clearly I was not sure that I would have time for a PhD. I mean, I would only have time for it if I gave birth during the program. (nr 4)

A few students also emphasized the disadvantage of their late enrollment, since in this way the period of becoming a mother will certainly overlap with their studies no matter how fast they try to finish their PhD. Therefore students who started their PhDs at later ages considered having their first child during the $\mathrm{PhD}$ education a less "bad" option:

Finishing the PhD or not (before childbearing) is not so decisively important for me now because I am old enough for childbearing. ( $n r 7)$

[...] if I were two years younger, I would probably say that I would finish (school before childbearing), because then I would be 28 by the time I finish, [...] but as I will soon be 26 (and have finished only 2 semesters), it is all the same if I do one more year, because I need to have a break no matter what. (nr 8)

The previously discussed results depict the contradictory character of value changes (Lesthaeghe, 2010) among highly educated Hungarian youths. Despite the general delaying trends in family formation, we found that these women reject the idea of late childbirth or total childlessness. Moreover, they insist on the very traditional notion of parenthood, thus they bear the sole responsibility for caring for the future child. This all reflects on the prevailing traditional family roles in Hungary (Pongrácz \& Molnár, 2011). All these ambiguities show the contradiction and struggle these women face, yet these remain at an individual level.

Furthermore, it can be said that the concept of motherhood resists value changes or deinstitutionalization in Hungary (Kohli, 2007). Thus, paradoxically, the strength and obduracy of this norm make the decisions on childbirth more difficult for Hungarian women, and, in turn, contribute to the low fertility rate. The present findings, however, support the thesis that despite their declared plans, at a certain age starting one's career cannot wait, whereas family foundation becomes less age-related (Huinink, 2013).

\section{Career Breaks and Labor Market Uncertainty}

For highly educated women, starting off a career and establishing a family occur broadly in the same life period. Besides the tension due to the conflicting social norms introduced above, $\mathrm{PhD}$ students faced another dilemma related to the timing of the first child: the question of when and how to interrupt their academic and professional careers.

Students in our sample took into consideration different pros and cons in order to choose the "least bad" timing of their career break. It is a fraught dilemma for them; one respondent - who had a workplace at the same time - believed that a career break literally meant a kind of termination of her academic progress. This exactly highlights how difficult it is for female researchers in academia to integrate motherhood into their career and how male and female life courses differ, 
as we described it earlier by Xie and Shauman's (2003) and Mason et al.'s (2013) earlier research.

We really have everything needed for having children. [...] My fiancé is all enthusiastic about it, but actually he won't have to quit his job. So when I decide that I'm willing to give up my professional career, we can immediately have a baby. ( $\mathrm{nr} 8$ )

Moreover, it was a general fear that their knowledge would be devalued no matter when they became mothers. For some of them, professional investment would be wasted, too:

I have spent five years at university, it was quite a long time, and a lot of work. It still hurts to think of it. And even now I work a lot and deal with development and research and it would be sad to leave it all behind. ( $\mathrm{nr} 8$ )

Students evaluated career breaks differently according to the junction of their academic career where they occur. As mentioned above, in general they saw three options for postponing their careers and having children: (1) before; (2) during and; (3) after their PhD studies, briefly discussed in terms of these options.

Firstly, except for one case, a career break before the PhD studies (i.e., between university graduation and $\mathrm{PhD}$ enrollment) seemed to be the "worst" timing for that event. We detected the earlier introduced (Probert, 2005; Haynes et al., 2012; Martinez et al., 2013) extremely high effect of the requirements of the so-called lock-step advancement behind these firm opinions: most of our respondents had enrolled into a $\mathrm{PhD}$ program in the academic year following university graduation; and almost all the students continued their academic progression to the next level due to the influence of their supervisors or other senior colleagues. All these had a significant influence on students' decisions on $\mathrm{PhD}$ enrollment and on the delay of the first childbirth.

Secondly, a career break during PhD training seemed to be the "least bad" option for some of the interviewees. Interviewees found that having the baby during $\mathrm{PhD}$ would allow them to reintegrate into the labor market. However, they all expressed their concerns related to work-life balance issues. $\mathrm{PhD}$ students with parallel work were the most concerned, for experiencing huge amount of workloads, including frequent overwork, as was the case in several European countries (Friesenhahn \& Beaudry, 2014). Though each of them introduced her PhD school as an institution that supports students' and employees' childbearing, they did have reservations about it. Some students projected a high level of uncertainty related to their future labor market opportunities due to childbearing:

My future career is uncertain in connection with this, because I don't know how I could leave, how I could return, how I could carry on, and who will say what to that. (nr 8)

So now I think the sooner the better (childbearing), but things like that make me feel insecure. By the way, there is this (industrial) scholarship thing, and I'm a bit concerned what the company would say if I stood in front of them saying that I don't want a scholarship for two years but I would actually like to return, it's just that now I have other business to attend to. ( $\mathrm{nr} 8$ )

The fear of negative attitudes towards mothers with little children can be better understood if we take into consideration that the Hungarian welfare system provides three years of parental leave. However, women who take a three year break face serious consequences in their careers. Though by avoiding the motherhood penalty they have a choice between shortening this period, or letting their partners take the parental leave, there is strong social agreement that mothers should stay at home up to the age of three of the child (Blaskó, 2005). All these fears and the expected negative consequences of the career break during PhD education have a crucial influence on women's fertility decisions. 
Most of the PhD students would have favored the option of having a first child after obtaining their $P h D$, but only if they did not considered it "too late" for motherhood, as we have already shown above. Moreover, a few of them would recommend an even greater delay in childbearing: women should first find a job after their $\mathrm{PhD}$, have a few years of labor market experience for they believed that they would have better salary prospects and probably also a better work-life balance. They planned to postpone childbearing in spite of the fact that they felt they would be "too old" for motherhood having spent some years working as a post-doc. They belonged to the older age group in our sample (age 28-29, compared with age 24-26). One student, who worked in industry, had a grim view of it:

For a woman to obtain a diploma but not finding a job it is a bit like committing a crime against herself. Especially if a mother with small children applies for a post without any work experience, she will be in a difficult situation. ( $\mathrm{nr}$ 11)

Those who considered their early post-doctoral years a good possible timing for the first child expressed their concerns about labor market uncertainty as well. They mentioned the uncertainty of fixed-term contracts that are typical in the case of young academics. This attitude is apparent in earlier empirical findings of Blossfeld et al. (2005), where results showed that women, firstly, experience high level labor market uncertainty in terms of short and fixed-term contracts, secondly, want to secure their career in the labor market first, and then become a mother:

On the other hand it's hard to acquire a position. If you don't get one, then it's common to make use of some grants [...] Which is good, but if you think about it, they could only get you financed for half a year or a year; it carries a lot of uncertainty. So from the point of view of childbearing it's very tricky when you should actually have a child. (nr 10)

To sum up the arguments presented above, our results show that uncertainty became a considerable problem even in highly educated youths' career and private life, which coincides with Blossfeld's earlier research findings. This vulnerability can be especially valid in the case of other low represented social groups in science, such as Black students of other students with color, let alone the special situation of intersectionality. The sources of the experienced uncertainty by our interviewees are manifold, and can be connected to both social norms and economic insecurities. At a general level, we have found evidence for the widespread use of short- and fixed-term contracts and the scarcity of tenure positions, which make career starts erratic (as Friesenhahn \& Beaudry (2014) have already shown). However, as mentioned earlier, life courses are highly gendered and influenced by ethnicity. There are risks of second-rate positions for women, especially for Black women, because they are often undervalued and segregated in the labor market and also have to reconcile motherhood and paid work (Beck, 1992; Jones et al., 2015). Social norms related to the three years of parental leave and that of women's almost sole responsibility for childcare also contribute to the increased level of insecurity. These often put even women scientists on a mommy track and hinder their return to their former career path.

\section{Laboratory Work}

Interviewees found the time of PhD education a "least bad" or, in a few cases, a "possibly good" life period for childbearing. In each case they emphasized that they found only the last part of $\mathrm{PhD}$ study - the period of dissertation writing - suitable for it.

Looking behind these data, a special feature of this field of engineering was revealed. In our sample, most PhD students' research and work involved laboratory work with chemicals. Many of the chemicals have hazardous effects on health, therefore researchers should be careful and keep to all safety regulations, especially female researchers. In the majority of cases, students finish the laboratory work required for their $\mathrm{PhD}$ research within the first three years of $\mathrm{PhD}$ enrollment. 
Even when some students in our sample who worked in a laboratory considered the early years of $\mathrm{PhD}$ education suitable for childbearing, they were not able to reconcile such a pregnancy with the risk of exposure to hazardous chemicals (Bellingham \& Sharpe, 2013). In sum, the health hazards of laboratory work played a further vital role in students' timing of motherhood. If a woman wants to have her child during her PhD course, she will probably have to schedule that after finishing her laboratory work. As a matter of fact, this affects women's timing at any time during their careers. Nevertheless, it gives food for thought: that pregnant students and researchers cannot be cautious enough, even if they adhere to every safety protocol and regulation rigorously. To put it differently, "normal accidents" (Perrow, 1984) can always happen as one of our interviewees' examples demonstrates:

As for me I learned about my pregnancy rather late, and I accidentally knocked over some carcinogenic solvent in the lab before I even knew. Well, the baby was affected a bit, but it was only for one or two days. (nr 4)

Another student called attention to the cumulative effects of chemicals and their role in the timing of children in terms of the whole lifespan:

The truth is that we do a lot of lab work, unfortunately I know this from experience about my colleagues - they unfortunately have several different health problems, especially from the past, which are just gynecological - that this may also suggest to women they had better have children as soon as possible, because no matter how careful we are about health and safety, these chemicals do not make childbearing any easier. ( $\mathrm{nr} 5$ )

To conclude this subsection, we can state that chemical engineering contains serious risks, particularly for women of childbearing age (Bellingham \& Sharpe, 2013). We found evidence that the interviewees were aware of these new types of emerging risks (Beck, 1992; Lupton, 1999). These chemicals might have harmful effects on their health; still, very often, the risks were unavoidable. These circumstances make scientific careers more troublesome for women. Furthermore, these results also raise questions such as how different types of (labor market, health, pregnancyrelated) risks interact with each other, and how female scientists attempt to tackle these risks to keep them at an acceptable level respectively.

\section{Discussion}

Our research results might contribute to the existing theoretical and empirical knowledge on the female life courses in STEM fields in several ways. In this last section of our paper we focus on the main three significant connections between our empirical results and the theoretical literature according our research questions. Firstly, we will discuss how our empirical findings about conflicting norms and processes in relation to motherhood can be linked to life-course research in general. Then we reflect on the possible relationships between social trends of uncertainty and life courses. Secondly, as far as the theory of risk society is concerned, we delineate certain presuppositions for future research about how different types of risks might overlap and interact with each other in the practice of female scientists.

Answering for the first research question, we explored those normative and institutional contexts that shape female PhD students' family plans. As for the life-course research, according to our viewpoint, the case of female PhD students exemplifies general societal trends concerning the situation of women. Life phases spent in education not only become longer, but also more important for the female population in general. Often, for a growing segment of this population, this time is further extended by some form of postgraduate study. As a result in relation to the timing of motherhood we found in line with Huinink's (2013) argument, that transitional phases concerning the family are often put on hold for some time. Firstly, in order to finish postgraduate education, which is clearly a strong social expectation towards youth, and also a criterion set by 
the students. Secondly, to establish a relatively secure career track and the necessary material conditions for family plans. These demands are clearly demonstrated by our results even if the public perceptions differ in this regard in Hungary (Pongrácz and Molnár, 2011). Meanwhile, results strengthen earlier empirical results (Xie \& Shauman, 2003; Castaño \& Webster, 2011) that male and female life courses differ, and females' choices are influenced by normative and institutional constraints.

Our research showed that different, even contradictory, processes of standardization and destandardization occur in relation to highly educated women's life courses. On the one hand, similarly to Western countries, there is an apparent de-standardization in the sequence of different life phases (education, work, childbearing) in Hungary. On the other hand, in the case of the investigated $\mathrm{PhD}$ education, a strong re-standardization process can be observed in terms of career steps. It is an open question, however, if we can generalize our results for similar life courses in STEMfields in CEE countries. Women already postpone their motherhood due to their undergraduate education, and the conflict between these opposing processes further postpones their childbearing. Moreover, the perceived risk of getting "too old" for having children appears as a final limiting factor that must be taken into consideration when women try to harmonize their different life phases. These three phenomena (standardization, re-standardization and the perceived biological limit), together with their respective orienting norms also in conflict with each other, create significant tension and paralysis by analysis (Schwartz, 2004) in the life of young female scientists and engineers. Secondly, the results of our research demonstrate that decisions in relation to one's life-course (starting, closing and "putting on hold" various life phases) are fraught with uncertainty (Blossfeld et al., 2005). This lingering uncertainty permeates the outcomes of $\mathrm{PhD}$ students' decisions in relation to harmonizing family and career steps. It explains why they could not really find good (or good enough) decisions for the timing of motherhood and its effect on their career. This led to a form of "decision inertia" while they searched for the "least bad" option. Moreover, these uncertainties could be witnessed in the case of labor market decisions, such as finding a position and returning after childbirth. Again, career progress (see the re-standardization argument above) with its clear and unambiguous steps was seen as a relatively stable point of reference compared to other areas of life.

Interviewees possess reflectivity in the Beckian sense. In other words, they are aware of their own situation and try to find solutions to the conundrums they faced. However, solutions identified by female PhD students are highly individualized and they do not reflect the fact their conditions might be the result of collective life situations needing collective answers either at the micro (sharing labor market uncertainties of having children with their partners) or the macro (changing child-care assistance provisions) level. Historically, it could be argued that coordinating transitions between life courses in the state-socialist era might have been easier as it was a heavily standardized and institutionalized "state assisted" matter. However, when this type of paternalism ebbed away, new tensions appeared due to de-standardization.

Lastly, in related to our second research question, one of the surprising and unexpected results of our research project is related to Beck's (1992) risk theory. It became apparent that a new "layer" of risks is added to job market related risks in the case of female chemical engineers. These are health related risks stemming from the fact that these women deal with hazardous chemicals during laboratory practice. It is particularly intriguing that while our research subjects are highly educated, possessing particularly comprehensive knowledge about these chemicals, they could still not adequately assess the risks of working in laboratories and being surrounded by dangerous substances. They could attempt to minimize these risks in a reflective fashion, yet they were also aware that the outcome would be highly uncertain in the long term. 


\section{Conclusions}

This paper aimed at exploring the timing of motherhood of $\mathrm{PhD}$ students in engineering with qualitative methods. It used a double theoretical framework of the life course and the risk/uncertainty approaches by which it showed how female life courses are shaped at the threshold of the research career. The most significant conclusion of this study is that, even as early as $\mathrm{PhD}$ education, young female engineers face continuous and serious dilemmas in relation to integrating motherhood into their career. On the one hand, our findings contribute to the theoretical discourses on the timing of motherhood of higher educated women. Despite the general pattern of delaying motherhood in developed countries, our research showed that women in post-graduation engineering trainings struggle against this postponement. They experience contradicting social norms in relation to the ideal timing of motherhood, let alone the strong social expectation of the long-term maternity leave in Hungary, that all are challenging circumstances for young female researchers especially in this male-dominated, knowledge-intensive profession. On the other hand, our results support that uncertainty and risk have a significant effect on young researchers' individual and family life courses. Both the experienced economic insecurities - especially in relation to motherhood - and the health and pregnancy risks women face in the case of laboratory work permeate young researchers' everyday life and decisions, which they can hardly avoid. For future research it could be a highly significant and interesting task to unravel how these different types of risks overlap and interact with each other; and how female researchers try to juggle these different risks in order to create an "optimal risk condition" for themselves and for their present and future children. The other implication of this study is that female $\mathrm{PhD}$ students in this research are left alone with the burden of shaping their early career, especially in a field where they hardly find any good practice or role model to follow. Findings of this research may call the attention of the stakeholders to the necessary intervention points.

\section{Acknowledgements}

This paper was prepared as part of a Hungarian Scientific Research Fund project (OTKA K104707). The title of the project: Dilemmas and strategies in reconciling family and work. We would like to express our gratitude for the dedication and energy of our fellow members in the "OTKA" research group. In one way or another they all contributed to this endeavor.

\section{References}

Altbach, P. G. (2000). The deterioration of the academic estate: International patterns of academic work. In P. G. Altbach (Ed.), The changing academic workplace: comparative perspectives (pp. 11-33). Chestnut Hill: Boston College Center for International Higher Education.

Ayre, M., Mills, J., \& Gill, J. (2013). 'Yes, I do belong': The women who stay in engineering. Engineering Studies, 5(3), 216-232.

Barrett, L., \& Barrett, P. (2008). The management of academic workloads. London: Leadership Foundation for Higher Education.

Beck, U. (1992). Risk society: Towards a new modernity. London: Sage.

Beck, U. (2000). The brave new world of work. Cambridge: Polity Press.

Bellingham, M., \& Sharpe, R. M. (2013). Chemical exposures during pregnancy: Dealing with potential, but unproven, risks to child health. Scientific Impact Paper, 37.

Berg, B. L. (2001). Qualitative research methods for the social sciences. Boston: Pearson.

Bernard, H. R., Killworth, P., Kronenfeld, D., \& Sailer, L. (1984). The problem of informant accuracy: The validity of retrospective data. Annual Review of Anthropology, 495-517. 
Bernardi Ć. L., Klarner Ć, A., \& von der Lippe, H. (2008). Job insecurity and the timing of parenthood: A comparison between Eastern and Western Germany. Europeran Journal of Population, 24, 287-313.

Berryman, S. (1983). Who will do science? Minority and female attainment of science and mathematics degrees. Trends and causes. New York: Rockefeller Foundation.

Bertrand Jones, T., Osborne-Lampkin, L., Patterson, S., \& Davis, D. J. (2015). Creating a "safe and supportive environment:" Mentoring and professional development for recent black women doctoral graduates. International Journal of Doctoral Studies, 10, 483-499. Retrieved from http://www.informingscience.org/Publications/2305

Blaskó, Zs. (2005). Dolgozzanak-e a nők?: A magyar lakosság nemi szerepekkel kapcsolatos véleményének változásai, 1988, 1994, 2002. (Should women work? Attitude changes in the Hungarian population towards gender roles, 1988, 1994, 2002). Demográfia (Demography), 2-3, 259-287.

Blickenstaff, J. C. (2005). Women and science careers: Leaky pipeline or gender filter? Gender and Education, 17(4), 369-386.

Blossfeld, H. P. (2007). Globalization and changes in life courses in modern societies. Conference presentation from $4^{\text {th }}$ European Conference on Complex Systems. Dresden. Retrieved from http://videolectures.net/eccs07 blossfeld_gcs/

Blossfeld, H. P., Klijzing, E., Mills, M. \& Kurz, K. (Eds.). (2005). Globalization, uncertainty and youth in society. London, New York: Routledge.

Castaño, C., \& Webster, J. (2011). Understanding women's presence in ICT: The life course perspective. International Journal of Gender, Science and Technology, 3(2), 364-386.

Conway, M. A., \& Pleydell-Pearce, C. W. (2000). The construction of autobiographical memories in the self-memory system. Psychological Review, 107 (2): 261.

Creswell, J. W. (1994). Research design: Qualitative and quantitative approaches. Thousand Oaks, CA: Sage.

Creswell, J. W. (2007). Five qualitative approaches to inquiry. Qualitative inquiry and research design: Choosing among five approaches. Thousand Oaks, CA: Sage Publications.

Creswell, J. W., \& Clark, V. L. P. (2007). Designing and conducting mixed methods research. Thousand Oaks, CA: Sage Publications.

Eccles, J. S. (2005). Studying gender and ehnic differences in participation in math, physical science, and information technology. In J. E. Jacobs \& S. D. Simpkins (Eds.), Leaks in the pipeline to math, science and technology careers (pp. 7-14). San Francisco, CA: Jossey-Bass.

Eurostat. (2012). Total fertility rate, 1960-2012. Retrieved from http://ec.europa.eu/eurostat/statistics$\underline{\mathrm{ex}-}$ plained/images $/ 7 / 77 /$ Total_fertility_rate $\% 2 \mathrm{C} \_1960 \% \mathrm{E} 2 \% 80 \% 932012 \% 28$ live births_per_woman $\% 2$ 9 YB14.png

Eurostat. (2013). Mean age of women at childbirth. Retrieved from http://ec.europa.eu/eurostat/tgm/table.do?tab=table\&plugin=1\&language=en\&pcode $=$ tps 00017

Evetts, J. (1994). Career and motherhood in engineering: Cultural dilemmas and individualistic solutions. Journal of Gender Studies, 3(2), 177-185.

Fábri, Gy. (2008). A felsőfokú reálképzés tényei és tétjei. (Facts and stakes of science higher education). Felsöoktatási Mühely (Higher Education Workshop), 4. Retrieved from https://www.felvi.hu/pub_bin/dload/FeMu/2008_04/oldal15_24_fabri.pdf

Fináncz, J. (2007). Doktoranduszok szakmai és magánéleti tervei. (Private life and career plans of PhD students). Educatio, 3,487-496.

Frierson, H. T. (1990). The situation of Black educational researchers: Continuation of a crisis. Educational Researcher, 19(2), 12-17.

Friesenhahn, I., \& Beaudry, C. (2014). The global state of young scientists. Project report and recommendations. Berlin: Akademie Verlag. 
The Timing of Motherhood While Earning a $\mathrm{PhD}$ in Engineering

Hareven, T. K. (1991). The history of the family and the complexity of social change. American Historical Review, 96(1), 95-124.

Hayes, A. R., \& Biglerb, R. S. (2013). Gender-related values, perceptions of discrimination, and mentoring in STEM graduate training. International Journal of Gender, Science and Technology 5(3), 254-280.

Haynes, C., Bulosan, M., Citty, J., Grant-Harris, M., Hudson, J., \& Koro-Ljungberg, M. (2012). My world is not my doctoral program ... or is it? Female students' perceptions of well-being. International Journal of Doctoral Studies, 7, 1-17. Retrieved from http://www.informingscience.org/Publications/1555

Hendrix, K. G. (2007). Neither white nor male: Female faculty of color. San Francisco, CA: Jossey-Bass.

Hilton, T. L., \& Lee, V. E. (1998). Students' interest and persistence. Journal of Higher Education, 59(5), 510-526.

Higginbottom, G. M. A. (2004). Sampling issues in qualitative research. Nurse Researcher, 12(1), 7-19.

Hirst, W., Coman, A., \& Coman, D. (2014). Putting the social back into human memory. In T. Perfect \& D. Lindsay (Eds.), The Sage handbook of applied memory (pp. 273-292). London: Sage Publications Ltd.

Huinink, J. (2013). De-standardisation or changing life course patterns? Transition to adulthood from a demographic perspective. In N. Gerda, A. Gunnar, G. Kulu H, L. Bernardi \& C. Bühler (Eds.), The demography of Europe (pp. 99-118). Netherlands: Springer.

Jacobs, J. A., \& Winslow, S. E. (2004). The academic life course, time pressures and gender inequality. Community, Work \& Family, 7(2), 143-161.

Jedlowski, P. (2001). Memory and sociology themes and issues. Time \& Society, 10(1), 29-44.

King, N. (1994). The qualitative research interview. In C. Cassell \& H. Symon (Eds.), Qualitative methods in organizational research (pp. 14-25, 33-35). London: Sage.

King, N. (2004). Using templates in the thematic analysis of text. In C. Cassell \& H. Symon (Eds.), Essential guide to qualitative methods in organizational research (pp. 256-270). London: Sage.

Király, G., Luksander, A., \& Paksi, V. (2013). Fiatalok munkanélküliségi kockázata Magyarországon és európai összehasonlításban (Youths' risk of unemployment in Hungary and in a European comparison). Kultúra és Közösség (Culture and Community), 44(3), 139-153.

Kohli, M. (2007). The institutionalization of the life course: Looking back to look ahead. Research in $\mathrm{Hu}$ man Development, 4(3-4), 253-271.

Křřžková, A., Nagy, B., \& Kanjuo M. A. (2010). The gender implications of labour market policy during the economic transformation and eu accession. A comparison of the Czech Republic, Hungary, and Slovenia. In C. Klenner and S. Leiber (Eds.), Welfare states and gender in Central-Eastern Europe (CEE) (pp. 329-361). Brussels: ETUI.

KSH (Central Statistical Office, Hungary) 2009. Obtained April 12, 2012 from the Office via email.

KSH (Central Statistical Office, Hungary) 2011. Obtained May 10, 2013 from the Office via email.

Lesthaeghe, R. (2010). The unfolding story of the second demographic transition. Population and Development Review, 36(2), 211-251.

Lupton, D. (1999). Risk. London. New York: Routledge.

Martinez, E., Ordu, C., Della S., Matthew, R., \& McFarlane, A. (2013). Striving to obtain a school-worklife balance: The full-time doctoral student. International Journal of Doctoral Studies, 8, 39-59. Retrieved from http://www.informingscience.org/Publications/1765

Mason, M. A., Wolfinger, N. H., \& Goulden, M. (2013). Do babies matter? Gender and family in the ivory tower. New Jersey: Rutgers University Press.

Mayer, K. U. (1993). Életutak és társadalmi változás. (Life courses and social change). Replika (Replicate), 9-10, 110-118.

Mynarska, M. (2010). Deadline for parenthood: Fertility postponement and age norms in Poland. European Journal of Population, 26, 351-373. 
Nagy, B. (2009). The paradox of employment and fertility: An introduction. Review of Sociology (Hungarian Sociological Association), 15(2), 47-56.

Nagy, B. \& Paksi, V. (2014). A munka-magánélet összehangolásának kérdései a magasan képzett nők körében (Questions of harmonising work-life balance among higher educated women). In Zs. Spéder (Ed.), A család vonzásában. Tanulmányok Pongrácz Tiborné tiszteletére (Family attractions. Studies in honour of Tiborné Pongrácz) (159-175.). Budapest: KSH NKI.

NSF report. (2014, table 54). Retrieved June 1, 2015 from https://www.nsf.gov/statistics/2016/nsf16300/data/tab54.pdf

NSF report (2014, table 62). Retrieved June 1, 2015 from https://www.nsf.gov/statistics/2016/nsf16300/data/tab62.pdf

Paksi, V., \& Szalma, I. (2009). Age norms of childbearing. Early, ideal and late childbearing in European countries. Review of Sociology of the Hungarian Sociological Association, 2, 57-80.

Palasik, M., \& Papp, E. (2007). Nők a tudományban. Attekintés Magyarországról. (Women in science. An overview about Hungary). Cseh Köztársaság Tudományos Akadémia Szociológiai Intézete (Institute of Sociology, Czech Academy of Sciences): Prague.

Palinkas, L. A., Horwitz, S. M., Green, C. A., Wisdom, J. P., Duan, N., \& Hoagwood, K. (2015). Purposeful sampling for qualitative data collection and analysis in mixed method implementation research. Administration and Policy in Mental Health and Mental Health Services Research, 42(5), 533-544.

Perrow, C. P. (1984). Normal accidents: Living with high-risk technologies. NY: Basic Books.

Pongrácz, T. (2012). Párkapcsolatok. (Partnerships). In P. Öri, \& Zs. Spéder (Eds.), Demográfiai Portré 2012 (Demographic Portrait 2012) (pp. 11-19). Budapest: KSH.

Pongrácz, T., \& S. Molnár, E. (2011). Nemi szerepek és a közvélemény változásának kölcsönhatása. (Interactions of gender roles and public opinion). In I. Nagy \& T. Pongrácz (Eds.), Szerepváltozások. Jelentés a nök és férfiak helyzetéröl (Changing Roles. Report on Women and Men) (pp. 192-206). Budapest: TÁRKI - Nemzeti Erőforrás Minisztérium.

Probert, B. (2005). I just couldn't fit it in: Gender and unequal outcomes in academic careers. Gender, Work \& Organization, 12, 50-72.

Schwartz, B. (2004). The paradox of choice. New York: Ecco.

She Figures (2012). She figures. Gender in research and innovation. Brussels: European Commission.

Sørensen, A. (1990). Unterschiede im lebenslauf von frauen und männer. In K. Mayer (Ed.), Lebensverläufe und sozialer Wandel (pp. 31). Kölner Zeitschrift für Soziologie und Sozialpsychologie. Sonderhef.

Spéder, Zs. (2007). Gyermekek: vágyak és tények. Dinamikus termékenységi elemzések (Children: Desires and facts. Dynamic fertility analyses). Életünk fordulópontjai, Mühelytanulmányok 6. (Turning Points in the Life course, Working Paper 6). Budapest: NKI.

Spéder, Zs. (2009). How are time-dependent childbearing intentions realized? Realization, postponement, abandonment, bringing forward. European Journal of Population, 25, 503-523.

Tight, M. (2010). Are academic workloads increasing? The post-war survey evidence in the UK. Higher Education Quarterly, 64, 200-215.

Tóth, O. (2002). Házasság és gyermek: vélekedés és viselkedés. (Marriage and child: Opinion and behaviour). Retrieved from http://www.c3.hu/scripta/szazadveg/11/toth.htm

Xie, Y. \& Shauman, K. A. (2003). Women in science. Career processes and outcomes. Cambridge, MA, London: Harvard University Press. 


\section{Biographies}

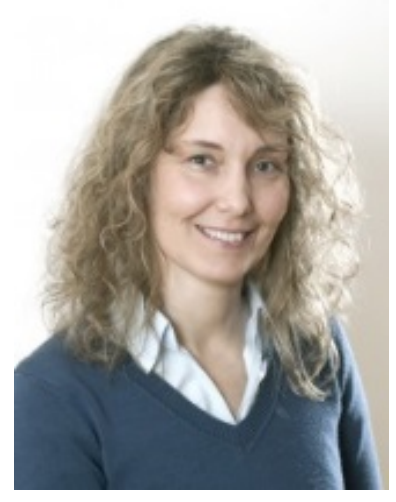

Veronika Paksi is a junior research fellow at the Institute of Sociology of the Centre for Social Sciences of the Hungarian Academy of Sciences. Her research field is women in science, especially the issue of work-family balance and childbearing. She is a $\mathrm{PhD}$ student at the Corvinus University of Budapest, editor of the Culture and Community Hungarian periodical and the head of secretariat of the Hungarian Sociological Association. She has participated in research that has focused on doctorate holders, on the age norms of childbearing and on the social construction of care. The topics of her recent publications are low representation of women in science, work-life balance of higher educated women, childbearing and uncertainty. She currently works in research projects dealing with network building and work-life balance of female researchers in science; as well as with inequalities in assisted reproductive technologies.

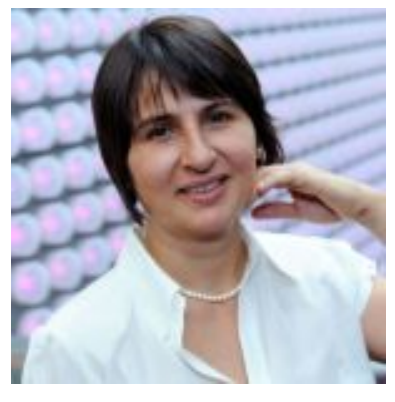

Beáta Nagy is an associate professor at the Corvinus University of Budapest. Her main research field is gender and work, especially management, organisations, and entrepreneurs. She received her $\mathrm{PhD}$ in sociology in 1996, and earned her habilitation doctorate in 2008. She is the co-director of the Gender and Cultural Centre at her university. Recently she has carried out investigations on companies' equal opportunity policies, the gender awareness of local governments and multinational companies, and a gender budgeting investigation. The latter was published by UN Women Hungary. She has recently finished a manuscript on the lack of female students in IT and technology. She is the head of the research group investigating the Dilemmas and strategies in reconciling family and work.

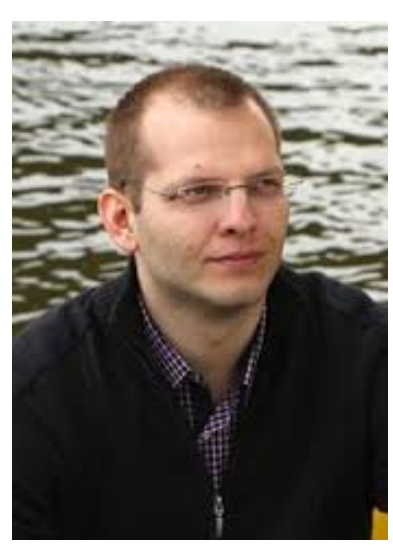

Gábor Király is a senior research fellow at the Budapest Business School and a senior lecturer at the Corvinus University of Budapest. His research fields include social issues of science and technology, public participation and the social and cultural contexts of decisionmaking, He defended his PhD thesis in 2009 at the Eötvös Loránd University of Sciences. He has worked in several domestic and international research projects aiming to engage stakeholders in discussing complex and technical issues. In the last few years his most important publications were about the relationship of public participation, social theory and future studies in international journals. For the time being, he aims to reveal how new technologies, especially info-communications and reproductive technologies, affect families and private life in general. 